\title{
Son Kolis - The Aboriginal inhabitants of Bombay (Now Mumbai) in transition
}

\author{
Sandeep Hegde \\ NMIMS University, V. L. Mehta Road, Juhu, Vile Parle (West), Mumbai 400056. India \\ E-mail address: sandeep.hegde@nmims.edu
}

Keywords: Koli, Kolis, Son Koli, Fishermen, Fishing, Aboriginal, Bombay, Mumbai, Commercial Fishing, Sustainability, Livelihoods, Tribe, Tribal, Communities.

\begin{abstract}
Son Koli, Macchimar Koli, Christian Koli, Vaiti Koli and Mangela Koli are fishermen by profession. Their main occupation is fishing. They are found along the North Konkan coast from Vasai, near Mumbai city to Ratnagiri district in south of Maharashtra.

Generations of these Kolis have been in the fishing occupation as their sole profession for survival. In spite of being settled in and around Mumbai city, which prides in calling itself the first metropolitan city of India, the Koli community has still retained the core of their traditional culture. They still distinguish themselves from the rest of the population in their customs and habits, and their social and religious life. This is largely due to their collective dependency on their only profession of fishing.

During the last two decades there has been rapid commercialization of fishing and related business activities like procurement, supply chain, and vending of the fishery products. Commercial fishing involving large corporations having license and territory demarcation use mechanized fishing using trawlers for catch. Also the profession has been infiltrated by other communities who had so far never been in this traditional profession. All these and many other socio-economic factors which have emerged lately have resulted in several challenges being posed for the Koli community of Bombay.
\end{abstract}

This research paper intends to highlight the past, the present and the future challenges that the Koli community faces at the thresholds of development and globalization.

\section{INTRODUCTION}

The Son Kolis are a fishing community of Bombay and certain nearby areas. The Kolis have inhabited Bombay from the very early times. Bombay once comprised of seven islands, namely Kolaba, Old Women's Island, Bombay, Mazagaon, Sion, Worli and Mahim. All these small islands were joined together by bridges and reclamations. Records of the earlier settlement of Bombay speak of Koli villages in all these seven islands. Most of these have still left their traces in the form of hamlets or gaontans and colonies where the Kolis still reside. There are Koliwadis or Koli settlements in Mahim, Sion and Worli. Mazagaon, it is believed, owes its name to fish, Machcha gaum, means "Fish Village" [1].

Enthoven (1922) [2] makes a general remark that Son Kolis are found along the north Konkan cost from Bassein (now Vasai region) to Ratnagiri. However their main stronghold is Alibaug taluka in Kolaba district. Alibaug is the residence of their hereditary "Sarpatil", the administrative head of their communal affairs. The seat of their communal deity is also in the same taluka, at Versali, nearly a mile from Alibaug town.

It can be said that as far back as the fifteenth century AD, Kolis and most probably Son Kolis, have inhabited the Bombay islands [1]. 


\subsection{Ethnographic profile of Kolis.}

\subsubsection{Name and Origin.}

Koli - a term of vague meaning covering a number of tribes of inferior status which have little in common beyond a position inferior to the Kunbi or the cultivating caste. The term Koli is almost certainly the origin of the word coolie, applied promiscuously in India by Europeans to manual labourers. [2]

Late Rev. John Wilson mentions that Son Koli to be the original inhabitants of Bombay islands, the Raj Koli of Jawhar and the North Konkan, the Mahadev and Malhar of the Deccan and the Kharvas and Agares of Surat and Thane.

The main groups within Kolis are the Malhar Kolis, the Mahadev Kolis, the Son Kolis and the Dhor Kolis. The latter are the lowest in the social scale and ear beef and the flesh of animals found dead in the jungle. The Malhar and Mahadev Kolis closely resemble the Marathas. These groups are: [3]

a. Gujarat Kolis - found in Panchmahals, Ahmedabad, Palanpur, Mahikantha, Kaira, Baruch and Surat districts of Gujarat.

b. Dhor Kolis - also called as the Tokre Kolis, are found chiefly in the North Konkan. The name Dhor comes from Dhor cattle, because they eat beef. Thokre, from thokar - a bamboo, refer to their calling as bamboo cutters.

c. Mahadev Kolis - are found in the valleys in the east slopes of the Sahayadris from Mulshi in the south-west of Poona to Trimbak in Nasik, a distance of 120 miles. They are also found westwards in Jawhar in the North Konkan and Mahadev hills, the traditional home of the Mahadev Kolis.

d. Malhar Kolis - or the Kolis worshipping the God Malhar, also called the Panbhari or the water filling Kolis, one of the purest and the most respectable of all Koli tribes. They are found in almost every village in the Deccan, in Bombay city and along the sea coast of the Thana district.

e. Son Kolis - are found along the North Konkan coast from Bassein to Ratnagiri in the south. The hereditary occupation of Son Kolis is fishing. [1]

Son Koli, Macchimar Koli, Christian Koli, Vaiti Koli and Mangela Koli are fishermen. Their main occupation is fishing. They are found along the North Konkan coast from Vasai to Ratnagiri in the South. All these Kolis are quite different from Schedule Tribes like the Mahadev Kolis and the Malhar Kolis in respect of groups, occupations, social customs and religious activities. The above Koli groups have separate ethnic entities. [4]

\subsubsection{The Habitat.}

The Son Kolis are a fishing community of Bombay and certain contiguous areas. In spite of being in and around Bombay, which prides in calling itself the first city in India, they still retain their traditional culture. They still distinguish themselves from the rest of the urban population in their customs and habits, their social and religious life, and so on.

In India a tribe is definitely a territorial group; it has a traditional territory and emigrants always refer to it as their home. [5]

The tribal India lives in the forests, hills and naturally isolated regions known as a rule by different names. This name has various meaning to include either the people of forests and hills or the original inhabitants of the place. The popular names are Vanyajati - denoting castes of the forests, Vanvasi - denoting inhabitants of the forest, Pahari - denoting hill dwellers, Ademjati - denoting original inhabitants, Adivasi - denoting first settlers, Janjati - denoting folk people, and Anusuchit Janjati - denoting Scheduled Tribes. This is also followed in our constitution covering them all. [5] 
Nearly all tribal people of India have been in almost continuous contact with their neighbours, who live by farming and a large number of specialized manual industries (Bose, 1971). Till today they have retained their customs and regulations; nearly all marry within their restricted local groups, and are sometimes guided by their own elders or political chiefs in their internal and external affairs. In other words, they form socially distinct communities in contrast to their neighbours. It is these communities which have been designated tribes, and listed in a schedule for special treatment. Barring a very small fraction, there is little difference between their economic life and that of their neighbouring rural folk. Yet, as the tribes have, more or less retained their separate social identity and, on the whole, can be regarded as comparatively isolated and economic backward, they have been placed under the category of Schedule Tribes. [6] There are altogether 427 tribal communities all over India (Roy, Burman, 1971).

Piddington (1956) says that "a group of people speaking a common dialect, inhabiting a common territory and displaying a certain homogeneity in their culture".

Hoebel (1949) opines that "a tribe is a social group speaking a distinctive language or dialect and possessing a distinctive culture that marks it off from other tribes. It is not necessarily organized politically".

A tribe is a social group of people who have the following nine features. [7]

a) A definite territory or who claim to occupy a common territory.

b) A common name.

c) A common dialect.

d) A common culture.

e) Behavior of an endogamous group.

f) Common taboos.

g) Existence of distinctive social and political systems.

h) Full faith in their leaders and

i) Self sufficiency in their distinct economy.

Various tribal groups have their own common names which are either generic or territorial in nature. They speak a common language or dialect of their own or their neighbourhood. The Oraons have their own language Kurukh. The Bhils speak Bhilli. All members of a tribe marry within themselves through exceptions are there in extreme cases. The political activities of the tribal India are of their own type and have their own arena. Firstly, the tribe, itself is the field in which there may be a number of panchayats on different groups or subgroup levels. Secondly, patriotism for one's village is common among the Indian tribes. The whole village stands firm for a common cause. They have full faith in their village headmen. Sometimes a single man combines in his person the political, social and sacred leadership of the village (Sachchidanand 1968).

The economy of the tribes is, to some extent, self sufficient in a restricted sense of the term and has a distinct feature of its own. Exploitation of nature is carried out in absence of technological aid. The profit motive in economic dealings and accumulation of wealth are generally absent. Mutual obligation, exchange of gifts, cooperative and collective endeavor and periodical markets are the important features of their economy.

\subsection{Social Status.}

Son Kolis have all the above characteristics of a social group of people to be called as a tribe. [8]

a) A definite territory or who claim to occupy a common territory.

Son Kolis occupy a definite territory of Bombay and nearby areas of Thana and Bassein regions near Bombay 
b) A common name.

Son Kolis are either Christian Kolis also called as Samvedi East Indian Kolis or Hindu Kolis.

c) A common dialect.

Son Kolis speak Marathi or some dialect of Marathi. [9]

d) A common culture.

The customs of rituals of marriage and other ceremony have commonalities irrespective of their religions. [9] According to Prof. Sanjay Ranade, a eminent sociologist studying the Son Koli community at Mumbai, "The most striking feature of the Kolis' world of faith and religious practice is that the deity appears unimportant. The Koli, it would seem, keeps his own requirements at the centre and chooses a deity who fulfils those requirements. This brings about an interesting situation. Is the Koli a tribal? Is the Koli a Hindu? Is the Koli a Muslim? Is the Koli a Christian? It would seem that the answer is that the Koli is just a Koli. In any Koli place of worship we find different articles of faith represented in an unabashed, honest manner." [10]

e) Behavior of an endogamous group, Common taboos, Existence of distinctive social and political systems and full faith in their leaders.

The Kolis as share a common social feature -- an intra-community dispute redressal system whereby all sorts of disputes among members and, at times, even with members of other communities, are settled through the agency of elders within the community. This is a characteristic of older communities in India that has been maintained in spite of emerging legal systems. [11]

f) Self sufficiency in their distinct economy.

Their main occupation is fishing, which has been carried out by the Koli community traditionally over several generations.

Therefore Son Kolis can be termed as a tribe due to the above characteristics. The Kolis were part of the reserved category of scheduled tribes, and many Kolis in the early-'50s and '60s got government jobs. Today, however, they have lost their scheduled tribe status in Mumbai following a court order. [11]

\section{BACKGROUND FOR TRANSITION OF SON KOLIS FROM MUMBAI CITY.}

Today Kolis reside in Koliwadas or Gaothans in the heart of Mumbai City. Areas like Khar Danda, Worli, Mahim, Versova, Gorai Creek and Manori Creek have small and big Koliwadas inhabited by Kolis. These Koliwadas are unique small villages within the Mumbai city. Each Gaothan having a huge area of land in the city most of which is in the prime property market.

Most of these properties is in close proximity to the coast or beaches, where the prices of property mushroom due to tourism boom and the hotel industry demands. Today most of these properties have landed with land sharks.

Under the liberalised coastal regulation zone (CRZ) rules of 2011, the Koliwadas have been placed under the CRZ- III category, making them eligible for a floor space index (FSI) - the ratio between the built-up area and the plot area available - of 2.5 as opposed to the earlier cap of 1.33 FSI. Most of these Koliwadas have high number of tenants who are not Kolis. Most of the benefits would be taken by them. The rest of the benefits would be taken by contractors and middlemen in this process. [12]

\subsection{Observation and Discussion.}

The Kolis are also helplessly surrendering their traditional habitat to land developers and touts as their traditional profession is being threatened by "Outsiders". Kolis now face threats to their traditional profession of fishing from large scale mechanization of fishing using trawlers on one hand ${ }^{\mathbf{1 9}}$ and influx of North Indians in this profession over the last few decades. Most of these North 
Indian fishermen buy the catch from wholesale commercial vendors and sell the fish at the doorsteps of the customer. The selling of fish has been traditionally done by the Koli women, who would collect the catch from their men folk and go regularly to the designated markets to vend the catch. This has been replaced by the North Indian men folk selling the fish locally without going to the designated markets. Due to sheer convenience of getting the catch at their door steps the customers avoid coming to the local markets for their purchases. These "Outsiders" have infringed upon the Kolis traditional profession and are posing a long term threat to their livelihood. [13]

Recently the fishermen community were planning to stage a strike against the Governments regulation on their profession. The protest was being organised by Akhil Maharashtra Macchimar Kruti Samiti (AMMKS). The Samiti is against the state government's decision regarding introduction of biometric identification cards and radio transmitters for use by fishermen. The total costs related to installing transmitters and carrying out a colour-coding procedure for the boat come to around Rs 35,000, which was being forced upon the Kolis. According to AMMKS there are bigger issues such as illegal fishing using Persian nets and encroachment of Indian waters by Bangladeshi fishermen. But, the government does nothing to address such issues. [14]

\subsection{Future challenges facing the Son Koli Community.}

\subsubsection{Territorial fishing rights.}

With the Government granting fishing rights to commercial players by demarcating them deep sea fishing areas, the traditional fishing community - the Son Kolis face several challenges today.

These heavy trawlers are only given licence to fish in deep sea, but when the catch becomes scarce they encroach on shallower territories, depriving the Kolis of their share. It seems that the authorities are hand in glove with the trawler owners, and our complaints are falling on deaf ears. [15]

\subsubsection{Traditional fishing patterns and ecological impacts.}

The traditional beliefs of the fishing community are: [16]

- Tidal waves are dependent on the moon position. High tides and low tides are dependent on the position of moon during the day time.

- High tide is in the North direction and low tide is in the South direction.

- If the wave direction is from West to East, the fish catch is less.

- After Diwali festival (October / November), the catch decreases and increases after March till May.

- From June to mid August (till Narali Purnima), fishing is not carried out.

All the above fishing beliefs of the community were based on their forefather's lore which had a scientific base. Traditionally, the fishermen used "Dol" method of fishing, which entailed use of fishing nets usually 240 feet long. These nets are placed 18 feet deep in water and the net is pulled one hour before the high tide begins. [16]

Today this technique of fishing, "Dol" has been replaced by commercial fishing using highly mechanised trawlers. Only commercial fishing companies use trawlers, as the cost of procurement is not affordable by the local fishing communities. The cost of a trawler could be upwards of Rs. 3 lacs. These trawlers fish in deep sea ignoring the nature's laws previously honoured by the Kolis. This has lead to depletion in the fish population. Further the traditional fishing season periods are not honoured by the commercial fishing companies thereby further depleting the catch as they encroach in the fish breeding seasons. [16] 
During the monsoon period, between June and August, fishermen stop going out to sea as their small boats can't cope with the high tide and turbulent sea. Moreover, it's the breeding season for fish - a time when millions of eggs are laid. But this does not deter the big trawlers from fishing. Despite the government prohibiting fishing during the monsoon period these trawlers often violate prohibitory orders and carry on fishing, destroying the eggs. This is one of the reasons often cited for shortage of fish in the sea. [17]

The chemical factories located near the coastline generally drain their waste directly into the sea and pollute it. There is also large-scale illegal sand dredging going on in the sea, as more sand is required to meet the demands of the growing construction industry. Due to the dredging the fish no longer come into the shallow waters, and that affects the catch. All these negative factors have led to the steady depletion of fish in the sea. [17]

\subsubsection{Suggestions.}

Unless there is some intervention by the state government in these issues mentioned above, the future for this aboriginal community is bleak. Since the community has been practicing this trade from the hunting and gathering stage of human existence and as fishing is considered as one such profession of hunting and gathering, there should be some protectionist measures to preserve the nature and the community.

Most of the community still practices the conventional frugal methods of livelihood. There could be re-skilling of the community workforce using modern techniques, but by retaining their traditional beliefs of protecting Mother Nature.

In today's era of financial inclusion, commercial banks and other financial institutions could offer soft loans to them for leasing out trawlers at least during the fishing seasons.

\section{CONCLUSION}

To conclude, though the very aboriginals of Mumbai City- the Kolis are visible in the panorama of cultural flux in everyday life of the city, they are slowly being transitioned to social extinction. This is due to the erosion of the two strong bonding for any community - the land and the profession. In the case of Son Kolis, they are slowly losing both of these in their ceaseless struggle for their existence.

\section{References}

[1] Vijaya B. Punekar, "The Son Kolis of Bombay”, Popular Book Depot, Bombay, 1959, pp. 1 5 .

[2] Enthoven, "The Tribes and Castes of Bombay", Volume II, 1922, pp. 243 - 260.

[3] Vidyarthi L. P., "Rise of Anthropology in India - A social science orientation", Volume I The tribal dimension, Concept Publishers, Delhi, 1978, pp. 253 - 263.

[4] Gare G. M, Aphale M. B., "The Tribes of Maharashtra”, 1982, pp. 38.

[5] Vidyarthi L. P., Rai, “The Tribal Culture of India”, Concept Publishers, Delhi, 1985, pp.62.

[6] Ibid, pp.25.

[7] Ibid, pp.167- 168 .

[8] Elsie W. Baptista, “The East Indians: Catholic Community of Bombay, Salsette and Bassein”, The Anthropos Institute Publication no.3, The Bombay East Indian Association, Bandra, Bombay, 1967. 
[9] James V., "Marriage Customs of Christian Son Kolis", Institute of Indian Culture, Bombay.

[10] Sanjay Ranade, "The Kolis of Mumbai at Crossroads: Religion, Business and Urbanisation in Cosmopolitan Bombay Today”, Monash Asia Institute (2012).

[11] http://infochangeindia.org/agenda/coastal-communities/communities-at-the-crossroads.html., April, 2010 - Accessed date : $15^{\text {th }}$ October 2015.

[12] http://www.dnaindia.com/mumbai/report-kolis-in-mumbai-find-new-crz-norms-a-fishyproposition-1495061. 16 January 2011. - Accessed date: $15^{\text {th }}$ October 2015.

[13] http://www.rediff.com/news/2004/feb/10sfa.htm., February 10, 2004. - Accessed date: $15^{\text {th }}$ October 2015.

[14] http://www.iamin.in/en/mumbai-south/news/kolis-go-indefinite-strike-against-stategovernment $\%$ E2\%80\%99s-apathy-53852., 23rd February 2015. - Accessed date: $15^{\text {th }}$ October 2015.

[15] http://www.thenational.ae/business/industry-insights/economics/mumbai-fishermen-squeezedout-by-giant-trawlers., $25^{\text {th }}$ January 2014. - Accessed date: $15^{\text {th }}$ October 2015.

[16] Y. N. Ulman, V. G. Naik, et al, "Traditional fishing practices and socio-cultural activities of Koli community in Konkan region of India.”, Asian Agri-History, Vol. 12, No.4 (2008),311 319.

[17] http://www.theguardian.com/world/2008/may/28/india-fishing., 28 ${ }^{\text {th }}$ May 2008. - Accessed date: $15^{\text {th }}$ October 2015 .

[18] Murphy R. X., "In transaction of the Bombay Geographical Society", 1844.

[19] Wilson John., "Aboriginal tribes of the Bombay Presidency", 1876.

[20] Sherring Rev., "Hindu tribes and castes", 1879.

[21] The Gazetteer of the Bombay Presidency, Volume XIII (Thana), 1882.

[22] The Gazetteer of the Bombay Presidency, Volume XI (Kolaba and Janjira), 1883. 